A N N A L E S

UNIVERSITATIS MARIAE CURIE-SKŁODOWSKA

LUBLIN - POLONIA

VOL. LXV, 1

SECTIO G

2018

University of Silesia, Katowice

xbb@interia.pl; slawomir.tkacz@us.edu.pl

AGNIESZKA BIELSKA-BRODZIAK

SŁAWOMIR TKACZ

\title{
Legislative Materials as the Legislator's Voice in the Discourse on Legal Principles ${ }^{1}$
}

Materiały legislacyjne jako głos prawodawcy w dyskursie o zasadach prawa

\section{INTRODUCTION}

This text brings together two incredibly interesting matters: legal principles, and legislative materials treated as an auxiliary tool in the interpretation of legal principles. For the purpose of this paper we shall assume that the use of legislative materials both for defining a catalogue of provisions that should be considered as legal principles, the content of the various principles, and the hierarchy between the various principles falls within the scope of interpretative activity.

Legal principles have been the subject matter of numerous publications in Polish literature. Yet, the issue has remained a matter of interest and controversy, as evidenced by works published in the period 2011-2014. ${ }^{2}$ Paradoxically, although it is indeed difficult to find a monograph which would not use the term "legal principles", there is no consensus as to the substance of this notion. What is especially interesting in this context is the relation legislative intent - legal principles.

1 Project financed by the Polish National Science Centre under grant no. DEC-2011/03/D/ HS5/02493.

2 We mean the following works: G. Maroń, Zasady prawa. Pojmowanie i typologie a rola w wyktadni i orzecznictwie konstytucyjnym, Poznań 2011; M. Kordela, Zasady prawa. Studium teoretycznoprawne, Poznań 2012; S. Tkacz, O zintegrowanej koncepcji zasad prawa w polskim prawoznawstwie (od dogmatyki do teorii), Torun 2014. In older literature: J. Wróblewski, Prawo obowiazujące a „ogólne zasady prawa”, „Zeszyty Naukowe Uniwersytetu Łódzkiego”, Nauki Humanistyczno-Społeczne, Seria I, t. 42, Łódź 1965, pp. 17-29; S. Wronkowska, M. Zieliński, Z. Ziembiński, Zasady prawa. Zagadnienia podstawowe, Warszawa 1974. 
The term "legal principle" is not unambiguous in jurisprudence, and discussions on this matter are accompanied by conceptual confusion. ${ }^{3}$ It is pointed out that the term "legal principle" "is attributed not one, but several fundamentally different meanings, and yet attempts to arrive at a definition are made as if in each case it is just one, always the same, concept". ${ }^{4}$ It is also noteworthy that various representatives of dogmatic disciplines formulate differing catalogues of legal principles and attribute various characteristics to them. Speaking of such discrepancies, we can identify the following groups of issues: a) understanding of legal principles; b) criteria for segregation of legal principles; c) relation legal principle - legal text; d) validity of legal principles; e) characteristics of legal principles; f) functions of legal principles and ways of using them in the process of application of the law.

The other issue that is a matter of interest of this paper is equally interesting. Legislative materials, perceived as a potential tool in the interpretation of the law, are undoubtedly one of the most discussed issues in the world in recent years. The discussion on ways of using legislative materials and the role they play or should play in the process of interpretation of the law is currently taking place in many countries all over Europe (Germany, ${ }^{5}$ Sweden, ${ }^{6}$ Great Britain, ${ }^{7}$ France, ${ }^{8}$ Spain $^{9}$ ), but also outside the European culture: in the United States (which is not just

3 M. Zieliński, Zasady i wartości konstytucyjne, [in:] A. Bałaban, P. Mijal (red.), Zasady naczelne Konstytucji RP z 2 kwietnia 1997 roku. Materiały 52. Ogólnopolskiego Zjazdu Katedr Prawa Konstytucyjnego w Międzyzdrojach (27-29 maja 2010 r.), Szczecin 2011, p. 21.

4 M. Zieliński, Konstytucyjne zasady prawa, [in:] J. Trzciński (red.), Charakter i struktura norm Konstytucji, Warszawa 1997, p. 59.

5 I have discussed the discourse taking place in German-speaking countries in the paper by A. Bielska-Brodziak, Cel interpretacji jako kryterium oceny przydatności materiałów legislacyjnych dla wyktadni prawa na gruncie niemieckiej kultury prawnej, [in:] M. Kłodawski (red.), Szkice z teorii tworzenia prawa i techniki legislacyjnej, in press.

6 On the role of legislative materials in interpretation of the law, see: H.H. Vogel, Sources of Swedish Law, [in:] M. Bogdan (ed.), Swedish Legal System, Stockholm 2010, pp. 30-34; A. Peczenik, G. Bergholz, Statutory Interpretation in Sweden, [in:] D.N. MacCormick, R.S. Summers (eds.), Interpreting Statutes: A Comparative Study, Dartmouth-Worcester 1991, pp. 311-357. In more general terms on the specific nature of the Swedish legal system, sources of the law and legislation, see: L. Carlson, The Fundamentals of Swedish Law, Lund 2009, pp. 23-52.

7 See e.g.: W.D. Popkin, A Dictionary of Statutory Interpretation, Durham 2007, pp. 160-161; $\mathrm{H}$. Fleischer, Comparative Approaches to the Use of Legislative History in Statutory Interpretation, "American Journal of Comparative Law" 2012, vol. 60, pp. 416-421; S. Beaulac, Parliamentary Debates in Statutory Interpretation: A Question of Admissibility or of Weight?, "McGill Law Journal" 1998, vol. 43, pp. 292-296.

8 See e.g.: a monograph by P. Josse, Le rôle de la notion de travaux préparatoires dans la jurisprudence du Conseil constitutionnel, Paris 1998; C.M. Germain, Approaches to Statutory Interpretation and Legislative History in France, "Duke Journal of Comparative and International Law" 2003, vol. 13, pp. 201-206.

9 See e.g.: P. Salvador Coderch, Los materials prelegislativos: entre el culto y la polémica, “Anuario de Derecho Civil” 1983, vol. 4, pp. 1657-1684. 
the cradle of this discussion, but which in fact keeps stirring it up, and keeps it on a very high level ${ }^{10}$ ), Australia, ${ }^{11}$ Canada,${ }^{12}$ New Zealand, ${ }^{13}$ or in Asian countries. ${ }^{14}$ The debate taking place involves not just interpreters but also the legislatures. ${ }^{15}$ It is also a trigger for discussions on the value of legislative materials for interpretation of the law. Legislative materials usually appear in the context of interpretation of the law under the name legislative history and refer to a set of documents drawn up in the course of the legislative process of an act. Legislative history allows the interpreter to obtain two types of important information: information on the meaning of the various words used by the legislator, and information on the objectives the legislator wanted to attain by introducing a given regulation. While this may apply to any provision, using legislative history towards provisions expressing legal principles.

\section{LEGAL PRINCIPLES AS A SPECIAL TYPE OF REGULATION}

Legal principles are mandatory legal norms characterised by certain features, which make it possible to segregate them and set them against those norms within the system, which are not considered to be legal principles. We shall leave outside the scope of our analysis these characteristics which use the notion of legal principles to describe the way legal concepts are formed or to present the leading ideas within a legal system. ${ }^{16}$

10 Due to the multitude of materials available, we shall quote here just some of the more important works devoted to using legislative history in the interpretation of law: the first one comes from the 1970s: G.B. Folsom, Legislative History. Research for the Interpretation of Law, Charlottesville 1972; the second one is Ch.E. Mammen, Using Legislative History in American Statutory Interpretation, Hague-London-New York 2002; see also: J.J. Brudney, Below the Surface: Comparing Legislative History Usage by the House of Lords and the Supreme Court, "Washington University Law Review" 2007, vol. 85, pp. 1-62. It is also worth drawing attention to the analyses of legislative materials usage in the American Supreme Court - see: B.M. Henschen, Judicial Use of Legislative History and Intent In Statutory Interpretation, "Legislative Studies Quarterly" 1985, vol. 3, pp. 353-371.

11 S. Beaulac, Parliamentary Debates..., op. cit., pp. 296-297.

12 S. Beaulac, Parliamentary Debates..., op. cit., pp. 300-308; S. Beaulac, Recent Developments at the Supreme Court of Canada on the Use of Parliamentary Debates, "Saskatchewan Law Review" 2000, vol. 63, pp. 581-616; R. Tremblay, L'essentiel de l'interpretation des lois, Quebec 2004.

13 S. Beaulac, Parliamentary Debates..., op. cit., pp. 297-298.

14 See: J. Evans, Controlling the Use of Parliamentary History, "New Zealand Universities Law Review" 1998, vol. 18, p. 1, footnotes 1 and 2.

15 See e.g.: comprehensive and detailed empirical study conducted in the legislative circles, described in a two-part work by A.R. Gluck, L.S. Bressman, Statutory Interpretation from the Inside - an Empirical Study of Congressional Drafting, Delegation, and the Canons, Part I, "Stanford Law Review" 2013, vol. 65, pp. 901-1025 and Statutory Interpretation..., Part II, "Stanford Law Review" 2014, vol. 66, pp. 725-801.

16 S. Wronkowska, M. Zieliński, Z. Ziembiński, Zasady..., op. cit., Chapter II. 
In the Polish legal culture the term "legal principle" is traditionally reserved for norms which are of a fundamental (underlying for the system) character. They are distinguished by an exceptional axiological, functional and hierarchical significance. ${ }^{17}$ The proposed criteria for selecting legal principles are diverse. However, it is stressed that their character is different from that of other norms and that the role they play in the system is special. It is emphasised that legal principles express (formulate the obligation to realise) values. For the most part, these are indeterminate norms, characterised by a high degree of generality. In the literature written after the system transformation of 1989, authors have also referred to characteristics of legal principles proposed by Ronald Dworkin, Robert Alexy, Manuel Atienza and Juan R. Manero, and Humberto Ávila. It is stressed that it is necessary to accept the differentiation between principles and rules. Principles are norms that are used to a larger or smaller extent in accordance with the maxim more or less. ${ }^{18}$ There are different ways to classify legal principles. In particular, complex divisions of principles, whereby in addition to principles in the strict sense of the word policies are selected, are accepted. ${ }^{19}$ Another point raised is that the legal text is merely a starting point that is supposed to be used in a specific way in the process of application of the law. ${ }^{20}$ Whether a given norm will be considered a principle is determined by how it is used in the discourse. Principles, as opposed to rules, which determine the contents of the decision, make it possible to conduct the argumentative process that leads to the issuance of the decision. They offer arguments for adopting a specific decision, or alternatively encompass merely part of the aspects that are important for the issuance thereof. ${ }^{21}$ Significant attention is also paid to (especially as part of the discourse on decisions of the constitutional court) to views held by Alexy. In particular, emphasis is drawn to his thesis that is used in the judgements of the Constitutional Tribunal and that states that legal principles are optimization requirements. This court treats constitutional principles as requirements that something be realised, to the greatest extent possible, given the legal and factual possibilities. ${ }^{22}$ Conflicts between the principles are settled by the court through the test of proportionality whereby conflicting interests are weighed. ${ }^{23}$

17 L. Leszczyński, G. Maroń, Pojęcie i treść zasad prawa oraz generalnych klauzul odsytajacych. Uwagi porównawcze, „Annales UMCS. Sectio G” 2013, vol. LX, nr 1, p. 81.

18 Cf. R. Dworkin, Taking Rights Seriously, Duckworth, London 1991; R. Dworkin, A Matter of Principle, Cambridge-Massachusetts-London 1985.

19 Cf. M. Atienza, J.R. Manero, A Theory of Legal Sentences, Dordrecht-Boston 1998, pp. 6-11.

20 H. Ávila, Theory of Legal Principles, Dordrecht 2007, p. 2.

21 Ibidem, pp. 133-134: "Principles are primarily complementary and partially preliminary norms, for although they cover only part of the aspects relevant to make a decision, they do not expect to generate a specific solution, but rather to contribute beside other reasons to make a decision".

22 R. Alexy, Theorie der Grundrechte, Baden-Baden 1985.

23 R. Alexy, On the Structure of Legal Principles, "Ratio Juris" 2000, vol. 13, no 3, p. 297 ff. 
The very fact that views like the ones we have discussed above exist makes it legitimate to conclude that there is indeed significant conceptual confusion surrounding legal principles. The fact that there are multiple views on this matter does not make the decision-making process easier. Since the various authors adopt different theoretical assumptions, their views are on many occasions incomprehensible for legal practitioners. Also, the situation is not made any better by the fact that authors of theoretical works use different sets of tools, which results in this complex matter being even more difficult to understand. Given the above, thinking about legal principles from the point of view of legislative intent appears highly desirable. It is beyond any doubt that documents drawn up in the course of the legislative process can be a valuable source of information for defining a catalogue of legal principles and content relating to the various principles. Referring to legislative history can prove helpful in identification of the legislator's intention as to a particular provision being "fundamental" and the ways it should be used in practice. As a result, analyses of legislative materials can help eliminate the discrepancies that have become visible in the discourse. To conclude, we would like to point out that legislative materials have scarcely been used in the discussion on legal principles. Nevertheless, it is our firm belief that they can be a useful tool in settling practical disputes on legal principles.

\section{RELATION BETWEEN THE LEGISLATOR AND LEGAL PRINCIPLES}

Literature offers a wide spectrum of views on the relation between the legislator and legal principles. Opinions on this matter can generally be divided into the following four groups:

3.1. Legal principles are created by the legislator; the legislator defines a catalogue of norms (which are legal principles) in legal texts; the role of legal writers and legal practitioners in this respect is to interpret (decode) the legislator's views laid down in legal texts;

3.2. Legal principles are created by authorities responsible for applying the law; whether a given norm created by the legislator will be recognised as a legal principle is determined by specific way in which it is used;

3.3. Legal principles must be anchored in legal texts - they are expressly worded in legal texts (or, alternatively, may be inferred from provisions of the law), and the "fundamentality" of the norm is determined by the type of requirement. An element that is necessary in determining whether a norm is a legal principle is opinio communis doctorum.

3.4. Recognition that a specific norm is a legal principle is a result of discourse between the legislator, legal writers, and authorities responsible for applying the law (courts). 
The discourse that is taking place in this context, leading to formulation of arguments for the "fundamentality" of the norm, is also leading to conviction that norms are fundamental for the system.

To recapitulate, in case of the first two groups of views, the process of identification of legal principles boils down to either activity of the legislator, or activity of authorities responsible for applying the law. However, the difference between the authors in the first or the second group is also related to other characteristic features of legal principles that either group highlights. The former attribute the legal principle status to norms that are more significant than other norms within the system, whereas others highlight the optimizing character of legal principles and the way that they are applied more or less. The views expressed by authors belonging to groups three and four reflect opinions that have recently been presented in Polish literature, according to which the legislator's activity is not the only factor that determines the "fundamentality" of a given norm. Views three (M. Kordela) and four (S. Tkacz) differ significantly as to whether a principle must be anchored in the legal text, or whether norms which are not provided for in legal texts can still be considered legal principles.

The Polish legal culture has a deeply ingrained image of legal principles as creations of the legislator. However, more recent publications tend to highlight another possibility: determination whether a specific norm should be considered a legal principle is the task of jurisprudence specialists (or authorities responsible for applying the law) who discuss legal texts created by the legislator. It is, therefore, a metalanguage statement about rules set forth by the legislator. While the voice of the legislator, who creates provisions of the law, is important, and in many cases can determine whether a given rule will become a legal principle, it is never the only factor to determine whether a norm is "fundamental".

\section{LEGISLATOR'S EXPRESSIONS ON LEGAL PRINCIPLES - POSSIBLE VARIANTS}

The legislator's expressions on legal principles may be divided into two categories:

4.1. Expressions presented in legal texts, among which the following can be identified:

4.1.1. Expressions presented in various sections of normative texts;

4.1.2. Expressions presented in a legal text outside the various sections of normative acts (chapter title);

4.2. Expressions presented outside legal texts (legislative materials).

\subsection{Expressions presented in legal texts}

4.1.1. When determining which norms should be considered legal principles, one first reaches for texts of normative acts. The problem with those is that while the legislator uses the term "principle", in legal texts it has many 
different meanings. In most cases, it is used to name some specific rules of conduct, in provisions referring to other provisions within a given act and in provisions which grant specific authorities the competence to make laws, in particular through executive orders. In those cases the legislator's use of the term "principle" results from certain linguistic traditions connected with drawing up legal texts. That said, the fact that the term "principle" is used, does not imply any criteria which determine that the norms in question ought to be recognised as legal principles.

A separate group is cases where the legislator uses a general clause and applies the term "principle" to authorise an authority responsible for applying the law to make an individual assessment, or allow for extratextual rules (e.g. the principle of social justice, principle of community life, etc.). These situations bring about numerous misunderstandings in the discourse and merit a separate analysis.

4.1.2. The term "principle" is also used to define titles of chapters of normative acts. Especially interesting are those situations wherein the term "principle" is collocated by the legislator with the adjective general or fundamental (as in General principles). The available literature offers two contrasting explanations for this type of legislative measure. Some authors maintain that by raising norms laid down in a given chapter to the status of general/ fundamental principles, the legislator in a way predetermines that they are legal principles and thus prevents the legal literature and case-law from doing so. Others, however, are of the opinion that such expressions are devoid of any significant cognitive values. It must be noted that in the situations discussed here we are dealing with a very strong manifestation of the legislative intent. It is evident that if the legislator selects a chapter labelled as general (fundamental) principles, the provisions laid down therein should in the first instance be examined as legal principles. This does not mean, however, that the legislator ultimately determines a closed catalogue of such fundamental principles. Experience shows that not all provisions placed by the legislator in a chapter of this kind are eventually recognised as legal principles, and that legal principles are looked for and ultimately connected with provisions set forth in other chapters of a normative act.

\subsection{Expressions presented outside legal texts - legislative materials}

Another category of sources of information on legal principles is information external in relation to a legal act, presented in legislative materials. These can be used to both determine which fragment of a legal act should - in accordance with the legislator's will - be treated as a principle (establishing a catalogue of 
legal principles), and to determine the contents of legal principles. Let us look at legislative materials (also referred to as preparatory works or travaux préparatoires) a little more closely. As mentioned before herein, the use of legislative materials for the purpose of interpretation of the law is called legislative history. The term originated in English-language literature, where it is used on a very wide scale. ${ }^{24}$ Conventionally understood, legislative history is a set of materials - drawn up in the form of documents - produced by the legislator (or commissioned by the legislator) in the course of drafting and passing of an act, with documents deriving from the parliamentary stage of the law-making process being the most important for the process of interpretation of the law. Legislative history is used in the process of interpretation of the law in that the interpreter accesses draft acts, explanatory statements, parliamentary debate records, or other legislative documents in order to develop, accept or reject interpretative hypotheses. The underlying objective is to obtain information allowing to identify the historic intention of the legislator behind the introduction of a given law or act. ${ }^{25}$

As far as the role of legislative materials among interpretation tools is concerned, it should be noted that Poland has not introduced, either statutorily or through established interpretation directives, any rules for using them. Therefore, there are no directives requiring or prohibiting using them. As a general rule, the Polish legal tradition has allowed the use of any and all materials which may prove useful in the course of interpretation of the law, although it is obvious that some interpretation tools will be more culturally valued and recommended than others. The use of travaux préparatoires in the process of interpretation of the law has until recently only received marginal interest, ${ }^{26}$ and yet their popularity in judicial decision making surprises by its scale: legislative process materials constitute an important and increasingly used interpretation tool. ${ }^{27}$ It ought to be noted that one of the main reasons for this is probably the fact that during the recent years, access to legislative materials has significantly improved due to unrestricted, relatively easy and convenient access to them via the Internet.

24 "Legislative history" is a highly popular term in Anglo-Saxon literature - cf. e.g. W.D. Popkin, A Dictionary of Statutory Interpretation, Durham 2007, pp. 160-183; also W.N. Eskridge Jr., Ph.P. Frickey, E. Garrett, Legislation and Statutory Interpretation, New York 2006, p. 303 (especially literature listed under footnote 17).

25 At this point, it is worth mentioning a similar term: "historical interpretation" - see more broadly: Z. Tobor, Wykładnia historyczna, [in:] Oprawie ijego dziejach księgi dwie: studia ofiarowane Profesorowi Adamowi Lityńskiemu w czterdziestolecie pracy naukowej i siedemdziesięciolecie urodzin, Białystok 2010, pp. 1177-1186; A. Bielska-Brodziak, Z. Tobor, Zmiana w przepisach jako argument $w$ dyskursie interpretacyjnym, „Państwo i Prawo” 2009, z. 9, pp. 18-32.

${ }^{26}$ First comprehensive study will soon be published by Wolters Kluwer - see: A. BielskaBrodziak, Śladami prawodawcy faktycznego. Materiały legislacyjne jako narzędzie wykładni, in press.

27 Ibidem. 


\section{LEGISLATIVE MATERIALS AS A TOOL FOR UNDERSTANDING LEGAL PRINCIPLES}

As indicated at the beginning of this paper, legislative materials are used for the purpose of interpretation of the law in two ways: ${ }^{28}$ in order to determine the underlying objective(s) behind the legislator's law-making activity, and as a dictionary, helping to define the meaning of a specific word, expression or phrase used in the act.

Analysis of the ways of using legislative history in interpretation of the law ought to start with a presentation of the different types of legislative materials. For the purpose of this paper, we shall focus on the following ones: explanatory statements to a bill, amendments presented in the course of legislative works (both those which resulted in modification of the draft and those that were rejected), committee reports, shorthand reports from committee and subcommittee works and plenary sessions of the legislative body, as well as opinions on the draft. As a general rule, all these materials are currently readily available for the interpreters in the public space (www.sejm.gov.pl).

To begin with, let us identify two spheres of analysis, which will help to systematize the issues we have been discussing herein. The first sphere is an analysis of reasons for using legislative history in the process of interpretation of the law (what is the interpreter trying to find in legislative history?), and the second one is an analysis of interpretation situations (interpretation problems), wherein legislative history proves useful (what problem is the interpreter trying to solve?). Regardless of what problem the interpreter is working on, they may resort to legislative history to find information either on the legislator's objective or on the meaning (of a particular word/phrase used in the wording of a provision of the law). ${ }^{29}$ In the first case, explanatory statements to bills will mostly be used,

28 Another important possible way of using legislative history in the process of interpretation of the law, which will not be discussed herein, is connected with the usefulness of legislative history for solving specific interpretation situations (problems). The Polish case-law highlights four most prominent situations in which preparatory materials are used: confirmation of a specific interpretation, selection from among several interpretation hypotheses, supplementation of the linguistic meaning, and breaking the linguistic meaning. The issue will be discussed in more detail in A. Bielska-Brodziak, Śladami prawodawcy faktycznego. Materiały legislacyjne jako narzędzie wyktadni, Chapter 5, in press.

29 Numerous publications in the English language highlight the two aforementioned reasons for using legislative materials. See e.g.: "As we will also see, there are different ways of using legislative history - as indicia of semantic »usage« or to determine "purpose «" - V.F. Nourse, Elementary Statutory Interpretation: Rethinking Legislative Intent and History, "Boston College Law Review" 2014, vol. 55, p. 1644. On the other hand, Linda D. Jellum writes about the use of legislative history to shed light on the detailed intention of the legislator as regards a specific problem and to identify the overall objective of a bill (law) - L.D. Jellum, Mastering Statutory Interpretation, 
as this type of documents covers explanation of the motives behind the legislator's law-making activity. It is worth noting that establishment of the objective is the prevailing reason for resorting to legislative history in decision-making practice. Using legislative history in this way also appears to be in accordance with the legal intuition. Analysis of the comprehensive background for a bill and conditions of the debate that precedes its entry into force offers the opportunity to understand the context of the legislator's activity and the objectives of the actual legislator. ${ }^{30}$ In the second case, identification of the meaning of a particular word or phrase calls for using different type of parliamentary documents. Here, the best way to obtain information on the particular meaning is through the observation of changes in a provision of the law as a result of amendments adopted, and through an analysis of amendments rejected. This will involve both draft modifications implemented through amendments (elimination of certain wording, introduction of other modifications to the existing wording of the draft), as well as explanatory statements to the amendments. Moreover, information can be found in opinions on the draft, including the reaction of the Sejm bodies to these opinions (whether they have been taken into account or ignored). It is worth adding that when looking for information on the meaning of a particular word or expression used by the legislator, a single legislative material is seldom used. Instead, interpreters usually carry out more comprehensive analyses of numerous documents. The opposite is the case when the interpreter is looking for information on the legislator's objective behind the introduction of a particular law. Then - as indicated above usually just explanatory statements are used.

Legislative materials can offer support in two situations connected with the specific nature of legal principles. To be more specific, they are helpful both for isolating a catalogue of principles (justifying that a given regulation is a principle), and for assigning normative content to legal principles. In order to visualise the way the legislator speaks about legal principles in legislative materials it is worth discussing examples. Let us briefly discuss the recent amendment of the Code of Administrative Proceedings, ${ }^{31}$ which added to an otherwise old act several new principles and introduced some modifications. Explanatory statement to the draft amendment provides a lot of valuable information on the legislator's objectives. It states that

Durham 2008, p. 169. Similar distinctions are available in the German literature - see: M. Übelacker, Die genetische Auslegung in der jüngeren Rechtsprechung des Bundesverfassungsgerichts, Kiel 1993, pp. 14-17.

$30 \mathrm{~S}$. Breyer, On the Uses of Legislative History in Interpreting Statutes, "Southern California Law Review" 1992, vol. 65, p. 848.

31 Act of 7 April 2017 amending the Code of Administrative Proceedings and certain other acts, Journal of Laws of 12 May 2017, item 935. 
The general principles of administrative proceedings (...) must be supplemented with new legal solutions (...). The draft explicitly expresses new principles in provisions of the Code of Administrative Proceedings on the assumption that it is necessary to provide legal framework for partnership-based approach of public administration to citizens through less restrictive and formalistic exercise of the regulatory power and of the possibility to decide cases not in accordance with legitimate interests of the parties. (...) the currently applicable set of general principles of administrative proceedings, as laid down in the Code, fails to fully implement the principles of the European soft law on good administration (...). The general principles presented below (...) define the obligations of authorities with respect to respecting the rights of individuals so as to protect them against excessive, unlawful actions by the authorities. These provisions have been formulated in a general manner, in accordance with the character and nature of general principles, whose content is subsequently fleshed out in the process of application of the law by administration authorities and is subject to control by administrative courts ${ }^{32}$.

Thus, as we can see, declarations on the objectives of the legislator significantly narrow down the scope of interpretation of any modifications introduced: the legislator's intention is to modify the catalogue of principles in such a way as to ensure on many levels better protection of citizens against actions by the state, even at the expense of interests of the state. The legislator's intention in this respect is to trigger more partnership-based relations between the state and citizens, allowing for more effective realisation of the principle of deepening of citizens' trust in public authorities (e.g. the principle of a friendly interpretation of the law and resolving factual doubts in favour of the party) and for the use of amicable dispute resolution methods (mediation).

The draft amendment discussed here also includes a range of expressions by the legislator that allow for the correct meaning to be attributed to particular words used in provisions which introduce new legal principles or modify their old wording. Let us present one example here - the new principle referred to in the explanatory statement to the draft as the principle of friendly interpretation of provisions of the law (in dubio pro libertate). It has been laid down in Art. 7 of the Code of Administrative Proceedings, and is worded as follows:

$\S 1$. If the subject of administrative proceedings is placing an obligation on a party or restricting or depriving a party of a right, and there are doubts as to the content of a legal principle, these doubts shall be settled in favour of the party, unless conflicting interests of the parties or interests of third persons directly influenced by the outcome of the proceedings require otherwise.

Legislative materials accompanying the draft offer valuable information which, on the one hand, confirms that the provision in question is to be recognised as a legal principle, and on the other one, determines how the provision and the

32 Explanatory statement to the governmental draft of the bill amending the Code of Administrative Proceedings and certain other acts, Sejm Paper no. 1183, Sejm of the $8^{\text {th }}$ term, p. 6. 
particular words used in it are to be understood..$^{33}$ Although the principle is new, the interpreter may find in its legislative history a number of directives helping to understand its nature. Its initiators have explained their motives behind the introduction of the principle in the following way:

Although the law ought to be formulated in such a way that establishing the meaning of its respective provisions should not pose difficulties, it cannot be excluded that such difficulties will indeed emerge. Introduced in Art. 7a of the Code of Administrative Proceedings the principle of "friendly interpretation of the law" is therefore intended to minimise the risk of burdening the party with consequences of the lack of clarity of the provisions. (...) it must be assumed that provisions whose wording raises doubts ought to be interpreted in such a way that the legitimate interests of citizens are not adversely affected. (...) Ambiguity of provisions of the law should not bring about negative consequences, especially for parties of administrative proceedings, whose objective is to impose an obligation (e.g. an administrative fine) on the party or restrict their right or deprive them of it. Hence, the draft introduces in Art. 7a of the Code of Administrative Proceedings a principle that in the event of administrative proceedings accompanied by doubts as to the content of a legal principle, the doubts ought to be settled in favour of the party. Thus, the party is protected against negative consequences of the creation of ambiguous provisions of the law and the resultant uncertainty. ${ }^{34}$

The provision's legislative history offers a description of cases in which the principle is to be applied. More specifically, it is maintained that the principle concerns situations

wherein interpretation of substantive rules, carried out in accordance with interpretation principles and directives resulting from jurisprudence, leads to several possible outcomes. It, therefore, applies to cases in which the authority - upon their analysis and objective assessment of the possible processes and interpretation outcomes - concludes that several of the interpretation outcomes may be considered correct as they follow from equivalent principles and methodologically correct and logical process of interpretation of the law. The principle in dubio pro libertate can, given its nature, be only applied during the final stage of the interpretation process. This is not to say, however, that it is superior to other interpretation principles. In fact, just the opposite is the case - the principle plays a complementary role, as it can only be used when the application of other interpretation principles has failed to give an unambiguous outcome. ${ }^{35}$

What is important, in conformity with the legislator's intention, while the principle requires that the authority considers the interpretation outcome postulated

33 For instance, it offers a precise explanation on how to understand the phrase "in favour of the party": "»In favour of the party« shall mean a legal solution that is optimal for the party out of all solutions that have emerged in the process of interpretation of the provision. Which of the interpretation outcomes is favourable (and in case of several ways of interpretation of the provisions that potentially meet the interests of the party - the most favourable one) should be determined by the position of the party, as resulting from its claim or indicated in the course of the proceedings, and not by an arbitrary assessment of the authorities" (p. 10 of the explanatory statement).

34 Explanatory statement to the draft, p. 7.

35 Explanatory statement to the draft, p. 9. 
by the party, it does not follow that the authority is obliged to automatically adopt it. Therefore, if the method of interpreting the law proposed by the party is manifestly contrary to its clear wording, explicitly violates the principles of logic or methodology of interpretation of the law, the principle in Art. 7a of the Code of Administrative Proceedings will not be applicable. In its assessment of whether a specific interpretation can be deemed correct, the authority should consider in particular the case law of the Court of Justice of the European Union. ${ }^{36}$ The precision of the information provided in the case discussed here is such that the draft initiators even point to specific cases where the principle of friendly interpretation is applied, and set out a desirable hierarchy of preference rules. ${ }^{37}$ Last but not least, legislative materials provide valuable information as to the relation between the principle in dubio pro libertate and other principles laid down in the Code of Administrative Proceedings. ${ }^{38}$

\section{SPECIFICITY OF USING LEGISLATIVE HISTORY FOR LEGAL PRINCIPLES - SEVERAL CONCLUDING REMARKS}

1. Both the catalogue of legal principles and the content of legal principles are established through discourse. One element of this discourse is the legislator's voice in the form of "traces" left in various places. The interpreter may resort to both the legislator's expressions in texts of normative acts and to expressions presented in legislative materials. An example of such "traces" is the fact that a specific norm was included in an act highly ranked in the hierarchy, in the scheme of the legislation at the beginning of the act, or in a chapter labelled as "legal principles". Another trace can be a declaration made by the legislator in the text of legislative materials, according to which a given provision is connected with a legal principle. It should be emphasised that the fact that the legislator has used in the normative act the word "principle" does not

36 Explanatory statement to the draft, p. 9.

37 "The principle may (...) for instance be applied when there are doubts as to whether systematic interpretation offers the final outcome of interpretation or whether it is necessary to apply functional interpretation, or when literal interpretation and systemic interpretation fail to produce the final outcome, and systematic interpretation leads to different outcomes when several equivalent objectives provided for a given legal norm are taken into account. These doubts can be eliminated when one method of interpretation is applied, and the principle laid down in Art. 7a of the Code of Administrative Proceedings indicated which method should be given priority by the authority" p. 10 of the explanatory statement to the draft.

38 "The principle in dubio pro libertate, therefore, constitutes a modification of the principle that interest of the society and legitimate interest of the party should be taken into account, as currently set forth in Art. 7a of the Code of Administrative Proceedings. That said, it should not be perceived as derogation from the principle of objective truth, which is also laid down in Art. 7a of the Code of Administrative Proceedings" - p. 10 of the explanatory statement to the draft. 
automatically mean that it is in fact a legal principle for the criteria of isolating legal principles are not "coded" in the meaning of the word "principle". Statements about "legal principles" may and indeed do concern any elements of an act, any provision or provisions. This is why representatives of the legal science and authorities responsible for application of the law, who in practice formulate a catalogue of legal principles, must go through various expressions by the legislator to find hints that a specific section or fragment of a legal text should be considered as a legal principle. In the process of determining which provision of the law ought to be regarded as a legal principle key role ought to be played by legislative history.

2. Given the indeterminateness of the wording of principles, the interpreting community has two possible directions when it comes to looking for information on the content of a principle: take into consideration the intention of the factual legislator, as expressed in legislative history, or complete the content of the principles without referring to parliamentary materials. The most desirable scenario is that both options are used, thus, ensuring comprehensive shaping of the normative content of legal principles. Naturally, in case of a conflict between interpretation hypotheses, the interpreter will have to choose between the hypothesis corroborated by information obtained from legislative history and the hypothesis corroborated by other interpretation tools (e.g. information from dictionaries or linguistic intuition). However - and it goes without saying - choosing from among comprehensively (and not selectively) analysed hypotheses is a measure of reliability and competence of an entity talking about legal principles.

3. It should be added that until recently - given the insufficient availability of legislative history in the public space - the main way of dealing with legal principles was creating their content without referring to legislative history. The situation is currently changing, as the access to legislative history has significantly increased and is still increasing. The turning point for Poland was introduction of Art. 61 into the Constitution. The article gives citizens the right to obtain information on the activities of organs of public authority. As citizens' access to legislative history has become easier and more comprehensive, we have witnessed increased usefulness of these documents in the process of application of the law. Although in our tradition the catalogue of legal principles and their content was not created based on legislative history, the currently available access opportunities offered by information technologies mean that expanding the context that shapes the catalogue and content of the various principles through the use of legislative materials is not just desirable, but in fact necessary. We believe this context is still underestimated and underused due to the historic lack of access to legislative history (which is not an issue any more). Legislative history may also help the interpreter in determining the hierarchy of principles. 
4. This paper is by no means a comprehensive study. Instead, it serves as a springboard for broader reflection. The problems that have been discussed here and that concern the use of legislative materials in the process of interpretation of the law, have hitherto only been discussed rudimentarily in the Polish local discourse on jurisprudence.

\section{BIBLIOGRAPHY}

Alexy, R., On the Structure of Legal Principles, "Ratio Juris" 2000, vol. 13, no 3.

Alexy, R., Theorie der Grundrechte, Baden-Baden 1985.

Atienza, M., Manero, J.R., A Theory of Legal Sentences, Dordrecht-Boston 1998.

Ávila, H., Theory of Legal Principles, Dordrecht 2007.

Beaulac, S., Parliamentary Debates in Statutory Interpretation: A Question of Admissibility or of Weight?, "McGill Law Journal" 1998, no. 43.

Beaulac, S., Recent Developments at the Supreme Court of Canada on the Use of Parliamentary Debates, "Saskatchewan Law Review" 2000, no. 63.

Bielska-Brodziak, A., Cel interpretacji jako kryterium oceny przydatności materiałów legislacyjnych dla wyktadni prawa na gruncie niemieckiej kultury prawnej, [in:] M. Kłodawski (red.), Szkice z teorii tworzenia prawa i techniki legislacyjnej, in press.

Bielska-Brodziak, A., Śladami prawodawcy faktycznego. Materiaty legislacyjne jako narzędzie wyktadni, in press.

Bielska-Brodziak, A., Tobor, Z., Zmiana w przepisach jako argument $w$ dyskursie interpretacyjnym, „Państwo i Prawo" 2009, z. 9.

Breyer, S., On the Uses of Legislative History in Interpreting Statutes, "Southern California Law Review" 1992, vol. 65.

Brudney, J.J., Below the Surface: Comparing Legislative History Usage by the House of Lords and the Supreme Court, "Washington University Law Review" 2007, no. 85.

Carlson, L., The Fundamentals of Swedish Law, Lund 2009.

Dworkin, R., A Matter of Principle, Cambridge-Massachusetts-London 1985.

Dworkin, R., Taking Rights Seriously, Duckworth-London 1991.

Eskridge, Jr W.N., Frickey, Ph.P., Garrett, E., Legislation and Statutory Interpretation, New York 2006.

Evans, J., Controlling the Use of Parliamentary History, "New Zealand Universities Law Review" 1998, no. 18.

Fleischer, H., Comparative Approaches to the Use of Legislative History in Statutory Interpretation, "American Journal of Comparative Law" 2012, no. 60.

Folsom, G.B., Legislative History. Research for the Interpretation of Law, Charlottesville 1972.

Germain, C.M., Approaches to Statutory Interpretation and Legislative History in France, "Duke Journal of Comparative and International Law" 2003, no. 13.

Gluck, A.R., Bressman, L.S., Statutory Interpretation from the Inside - An Empirical Study of Congressional Drafting, Delegation, and the Canons, Part I, "Stanford Law Review" 2013, no. 65 .

Gluck, A.R., Bressman, L.S., Statutory Interpretation from the Inside - An Empirical Study of Congressional Drafting, Delegation, and the Canons, Part II, "Stanford Law Review" 2014, no. 66 .

Henschen, B.M., Judicial Use of Legislative History and Intent in Statutory Interpretation, "Legislative Studies Quarterly" 1985, no. 3.

Jellum, L.D., Mastering Statutory Interpretation, Durham 2008. 
Josse, P., Le role de la notion de travaux preparatoiresdans la jurisprudence du Conseil constitutionnel, Paris 1998.

Kordela, M., Zasady prawa. Studium teoretycznoprawne, Poznań 2012.

Leszczyński, L., Maroń, G., Pojęcie i treść zasad prawa oraz generalnych klauzul odsyłających. Uwagi porównawcze, „Annales UMCS. Sectio G” 2013, vol. LX, nr 1.

Mammen, Ch.E., Using Legislative History in American Statutory Interpretation, Hague-LondonNew York 2002.

Maroń, G., Zasady prawa. Pojmowanie I typologie a rola w wyktadni i orzecznictwie konstytucyjnym, Poznań 2011.

Nourse, V.F., Elementary Statutory Interpretation: Rethinking Legislative Intent and History, "Boston College Law Review" 2014, no. 55.

Peczenik, A., Bergholz G., Statutory Interpretation in Sweden, [in:] D.N. MacCormick, R.S. Summers (eds.), Interpreting Statutes: A Comparative Study, Dartmouth-Worcester 1991.

Popkin, W.D., A Dictionary of Statutory Interpretation, Durham 2007.

Salvador Coderch, P., Los materials prelegislativos: entre el culto y la polémica, "Anuario de Derecho Civil" 1983, no. 4.

Tkacz, S., O zintegrowanej koncepcji zasad prawa w polskim prawoznawstwie (od dogmatyki do teorii), Toruń 2014.

Tobor, Z., Wyktadnia historyczna, [in:] O prawie i jego dziejach ksiegi dwie: studia ofiarowane Profesorowi Adamowi Lityńskiemu w czterdziestolecie pracy naukowej i siedemdziesięciolecie urodzin, Białystok 2010.

Tremblay, R., L'essential de l'interpretation des lois, Quebec 2004.

Übelacker, M., Die genetische Auslegung in der jungeren Rechtsprechung des Bundesverfassungsgerichts, Kiel 1993.

Vogel, H.H., Sources of Swedish Law, [in:] M. Bogdan (ed.), Swedish Legal System, Stockholm 2010.

Wronkowska, S., Zieliński, M., Ziembiński, Z., Zasady prawa. Zagadnienia podstawowe, Warszawa 1974.

Zieliński, M., Konstytucyjne zasady prawa, [in:] J. Trzciński (red.), Charakter i struktura norm Konstytucji, Warszawa 1997.

Zieliński, M., Zasady i wartości konstytucyjne, [in:] A. Bałaban. P. Mijal (red.), Zasady naczelne Konstytucji RP z 2 kwietnia 1997 roku. Materiały 52. Ogólnopolskiego Zjazdu Katedr Prawa Konstytucyjnego w Międzyzdrojach (27-29 maja 2010 r.), Szczecin 2011.

\section{SUMMARY}

The paper discusses the possibilities for using legislative materials in the process of establishing a catalogue of legal principles and determining their content. The starting point for the analysis was the conviction that the catalogue of legal principles and their content is established through discourse. One element of this discourse is the legislator's voice in the form of "traces" left in various places. The interpreter may refer to both the legislator's expressions in texts of normative acts and to expressions presented in legislative materials. Until recently, given their insufficient availability, legislative materials were seldom used in the discourse on legal principles. Through an analysis of legislative materials developed for the 2017 amendment of the Code of Administrative Proceedings, which introduced new principles to the Code, the authors show that these materials can be a source of valuable information on the legislative intent. The paper concludes with the following observation: the currently available access opportunities offered by information technologies mean that expanding the context that shapes the catalogue and content of the various principles through the use of legislative materials appears necessary. 
Keywords: legal principles; legislative materials; legislative history; legislator; Code of Administrative Proceedings

\section{STRESZCZENIE}

Przedmiot rozważań podjętych w opracowaniu stanowi kwestia możliwości wykorzystania materiałów legislacyjnych w procesie określania katalogu zasad prawa oraz ustalania ich treści. Punktem wyjścia dla zaprezentowanych przez autorów analiz było przekonanie o tym, że ustalenie katalogu zasad prawa i ich treści jest budowane w drodze dyskursu. Elementem tego dyskursu jest głos prawodawcy w postaci „śladów” pozostawionych w różnych miejscach. Interpretator może zarówno sięgać po wypowiedzi prawodawcy znajdujące się w tekstach aktów normatywnych, jak i wykorzystać wypowiedzi zaczerpnięte z treści materiałów legislacyjnych. Do niedawna - w związku z brakiem wystarczającej dostępności dokumentów wytworzonych w toku procesu legislacyjnego - materiały te były bardzo rzadko wykorzystywane w dyskursie o zasadach prawa. Autorzy na przykładzie analizy materiałów legislacyjnych powstałych w toku dokonanej w 2017 roku nowelizacji Kodeksu postępowania administracyjnego z 1960 roku, której efektem było wprowadzenie do prawa administracyjnego procesowego nowych zasad i poddanie pewnym modyfikacjom dotychczas uznawanych, dowodzą, że materiały te mogą być cennym źródłem informacji o intencji prawodawcy. Na zakończenie rozważań sformułowano wniosek ogólny, że mimo iż w naszej tradycji nie dokonywano odtwarzania katalogu i treści zasad prawa w oparciu o materiały legislacyjne, wobec aktualnych możliwości dostępu jakie dają technologie informatyczne, wzbogacenie kontekstu decydującego o ustaleniu katalogu i treści poszczególnych zasad przez wykorzystanie materiałów legislacyjnych wydaje się kierunkiem niezbędnym.

Słowa kluczowe: zasady prawa; materiały legislacyjne; historia legislacyjna; prawodawca; Kodeks postępowania administracyjnego 
